\title{
Serum Immune Markers Differentiation in Patients With Puumala or Dobrava Virus Infections
}

\author{
Alemka Markotić ${ }^{1,2,3}$ (D), Ljiljana Žmak ${ }^{4,5}$, Alenka Gagro ${ }^{6,7}$, Dragan Dekaris ${ }^{8}$ \\ ${ }^{1}$ University Hospital for Infectious Diseases, Zagreb, Croatia; ${ }^{2}$ School of Medicine, University of Rijeka, Rijeka, Croatia; \\ ${ }^{3}$ Catholic University of Croatia, Zagreb, Croatia; ${ }^{4}$ Croatian Institute of Public Health, Zagreb, Croatia; ${ }^{5}$ School of Medicine, \\ University of Zagreb, Zagreb, Croatia; ${ }^{6}$ Children's Hospital Zagreb, Croatia; ${ }^{7}$ School of Medicine, Josip Juraj Strossmayer \\ University, Osijek, Croatia; ${ }^{8}$ Croatian Academy of Sciences and Arts, Zagreb, Croatia
}

OPEN ACCESS

Correspondence: Prof. Alemka Markotić MD PhD alemka.markotic@bfm.hr orcid.org/0000-0003-4104-7940

This article was submitted to RAD CASA - Medical Sciences as the original article

Conflict of Interest Statement: The authors declare that the research was conducted in the absence of any commercial or financial relationships that could be construed as a potential conflict of interest.

Received: 22 June 2019 Accepted: 24 June 2019 Published: 22 July 2019

Citation: Markotic A, Zmak L, Gagro A, Dekaris D. Serum immune markers differentiation in patients with Puumala or Dobrava virus infections.

RAD CASA - Medical Sciences. 537=46-47 (2019): 9-15 DOI: $10.21857 / \mathrm{mjrl} 3 \mathrm{ux} 1 \mathrm{~g} 9$

Copyright (C) 2019 Markotic, Zmak, Gagro and Dekaris. This is an open-access article distributed under the terms of the Creative Commons Attribution License (CC BY). The use, Attribution License (CC BY). The use, forums is permitted provided forums is permitted, provided the original author(s) and the copyright owners(s) are credited and that the original publication in this journal is cited, in accordance whit accepted adacemic practice. No use, distribution or reproduction is permitted which does not comply with these terms.

\begin{abstract}
:
Hemorrhagic fever with renal syndrome (HFRS) is widely distributed in Europe and caused mostly by two different orthohantaviruses: Puumala virus (PUUV) and Dobrava virus (DOBV). Several studies have implicated that HFRS is an immunologically mediated disease and that the proinflammatory cytokines may have a role in the immunopathogenesis of HFRS. In this study, we have detected: IL-2; IL-6; their soluble receptors (sIL-2R, sIL-6R); TNF-alpha; sCD23; and total IgE in two consecutive sera of HFRS patients, and have looked for their possible relation with the main blood and biochemical findings in order to determine their possible role in disease progression. The differences in the level of measured parameters between PUUV- and DOBV-infected patients were also observed. The sIL-2R, sIL-6R and sCD23 levels were elevated in all HFRS patients, but we did not find any statistical difference between 1st and 2nd sera. The total IgE was elevated in about 1/3 of HFRS patients in both sera. We detected higher IL-6, sIL-2R and sCD23 levels in the sera of patients with DOBV infection than in patients with PUUV infection, with no statistically significant difference. The total IgE level was elevated in five of the six tested patients with DOBV infection, and they had a statistically higher level of total IgE than patients with PUUV infection. Almost all the listed biochemical and blood parameters in HFRS patients stand either in positive or in negative correlation with sIL-2Rapha. The levels of urea and creatinine, which are the hallmarks of HFRS severity, stand in positive correlation with sIL-2Rapha, IL-6, sIL-6R and sCD23. The level of the total IgE stands either in positive or in negative correlation with proteins and parameters of the liver function. We have also found a high positive correlation between the total IgE level and basophile count.
\end{abstract}

KEYWORDS: orthohantaviruses, Puumala Virus, Dobrava virus, immune parameters, cytokines

\section{SAŽETAK:}

Hemoragijska vrućica s bubrežnim sindromom (HVBS) široko je rasprostranjena u Europi, a uzrokovana je uglavnom dvjema različitim ortohantavirusima: virusom Puumala (PUUV) i virusom Dobrava (DOBV). Nekoliko studija implicira da je HVBS imunološki posredovana bolest i da proinflamatorni citokini mogu imati ulogu u imunopatogenezi HFRS. U ovoj smo studiji određivali: IL-2, IL-6, njihove solubilne receptore (sIL-2R, sIL-6R), TNF-alfa, sCD23 i ukupni IgE u dva uzastopna seruma pacijenata s HVBS-om i tražili njihovu moguću vezu s glavnim hematološkim i biokemijskim nalazima, kako bi se utvrdila njihova moguća uloga u progresiji bolesti. Također su analizirane razlike u razini izmjerenih parametara između bolesnika inficiranih PUUV i DOBV. U svih bolesnika s HVBS-om, razine sIL-2R, sIL-6R i sCD23 su bile povišene, ali nismo pronašli statističku razliku između prvog i drugog seruma. Ukupni IgE je povišen u oko 1/3 HFRS pacijenata u oba seruma. U serumu bolesnika s DOBV-infekcijom utvrđene su više razine IL-6, sIL-2R i sCD23 nego u bolesnika s PUUV- infekcijom, bez statistički značajne razlike. Ukupna razina IgE bila je povišena u pet od šest testiranih bolesnika s DOBV-infekcijom i imali su statistički značajno višu razinu ukupnog IgE od bolesnika s PUUV-infekcijom. Gotovo svi navedeni biokemijski i hematološki parametri u HVBS-bolesnika su u pozitivnoj ili negativnoj korelaciji sa sIL-2R. Razine ureje i kreatinina, koje su obilježja težine HVBS-a, su u pozitivnoj korelaciji sa sIL-2Ra, IL-6, sIL-6R i sCD23. Razina ukupnog IgE je u pozitivnoj ili negativnoj korelaciji s proteinima i parametrima funkcije jetre. Utvrdili smo i visoku pozitivnu korelaciju između ukupnog IgE i bazofila.

KLJUČNE RIJEČI: ortohantavirusi, virus Puumala, virus Dobrava, imunološki parametri, citokini 


\section{INTRODUCTION}

The most important genus of the family Hantaviridae is orthohantavirus (HTV), which now comprises 36 viral species ${ }^{1}$. This group of RNA viruses is related to two different syndromes: hemorrhagic fever with renal syndrome (HFRS) and hantavirus pulmonary syndrome (HPS) ${ }^{2}$. HFRS is widely distributed in Europe and caused mostly with two different HTV: Puumala virus (PUUV) usually causes mild or moderate HFRS disease and Dobrava virus (DOBV), which is usually associated with severe disease, but exceptions are also reported ${ }^{3,4,5}$.

Following the incubation period, HFRS is manifested mainly by fever, variable degrees of circulatory failure, hemorrhage and renal failure, but the symptoms demonstrating the involvement of other organs and systems are also observed ${ }^{3,4,5}$. As there is a considerable variation among patients in the clinical manifestations of the disease, an attempt was made to link the type of hantavirus (HTV) with the severity of the disease, but also to put it in the relationship with some genetic and/or immunological characteristics. There is evidence that the severity of HFRS caused by Puumala virus is associated with a certain HLA haplotype $e^{6}$. The study of the pathogenesis of HFRS in vivo is limited by the lack of a suitable animal model ${ }^{7}$, so the mechanisms underlying the induction of HFRS symptoms and manifestations are largely unknown. Several studies support the view that HFRS is an immunologically mediated disease with thrombocytopenia and vascular dysfunction (mainly due to capillary leakage) as the central physiologic derangement ${ }^{5,7,8}$.

Some studies have implicated that the proinflammatory cytokines: interleukin (IL)-1, IL-6 and tumor necrosis factor alpha (TNF-a) may have a role in the immunopathogenesis of HFRS 9,10,11,12. Khaiboullina et al., recently showed distinct cytokine profiles between HFRS and HPS ${ }^{13}$. The role of soluble CD23 (sCD23) and immunoglobulin E (IgE) in HFRS immunopathogenesis was also considered of importance ${ }^{14,15,16}$. The possible importance of sIL-2 receptor (sIL-2R) and its potential correlation with some clinical laboratory parameters and severity of HFRS in patients infected with Puumala or Hantaan (HTNV) virus has also been presented ${ }^{11,17,18,19}$.

In this study, we detected: IL-2, IL-6, their soluble receptors (sIL-2R, sIL-6R), TNF-alpha, sCD23 and total IgE in two consecutive sera of HFRS patients and looked for their possi- ble relation with the main blood and biochemical findings in order to determine their possible role in disease progression. The differences in the level of measured parameters between PUUV and DOBV infected patients were also observed for the purpose of analyzing their role in the distinction of patients infected with one of the viruses and eventual association with the severity of clinical picture.

\section{Patients and Methods}

The information about the number of tested patients and the sera collected during the HFRS course (at admission and before dismission to the hospital), the day of blood collection and the tested immunological parameters are described in table 1 . The patients were hospitalized in few clinical centers in Croatia. Specific antibodies to PUV or DOBV were detected using ELISA $\operatorname{IgM}$ and IgG tests as previously described [4]. Patients were categorized into the DOBV or PUUV infection groups. Biochemical and blood findings were analyzed in 30 HFRS patients hospitalized at the University Hospital for Infectious Diseases in Zagreb, and their case records were retrospectively reviewed. All patients signed an informed consent and the study was approved by The University Hospital for Infectious Diseases Ethical Committee.

\section{Measurement of immunological parameters.}

IL-2, sIL-2R, IL-6, sIL-6R and TNF-alpha were measured by commercial ELISA kits (QuantikineTM, R\&D Systems, Minneapolis, USA). According to the manufacturer's protocols, the upper limits for the normal human sera for IL-2 were as follows: IL-2 31 pg/mL, IL2R 2132 pg/mL, IL-6 10 pg/mL, sIL-6R 46 $\mathrm{ng} / \mathrm{mL}$ and TNF-alpha $39 \mathrm{pg} / \mathrm{mL}$.

Soluble CD23 was measured by use of ELISA kit (The Binding Site Limited, Birmingham, UK). According to the manufacturer's protocol, the range for sCD23 for normal sera was 1-6 pg/L. Total IgE was determined using radioimmunosorbent assay (Institute of Immunology, Zagreb, Croatia), as previously described ${ }^{20}$. Total $\mathrm{IgE}$ values $>120 \mathrm{kU} / \mathrm{L}$ were considered elevated.

\section{StATISTICAL ANALYSIS.}

Data between groups were compared with the Wilcoxon matched pairs test. Pearson product-moment correlation was

Table 1. The number of sera obtained from HFRS patients two times during the HFRS course and used for the measurement of the immunological parameters (sCD23, IgE, IL-2, sIL-2Rapha, IL-6, IL-6 sR and TNF-apha).

\begin{tabular}{|c|c|c|c|c|c|c|c|c|c|c|}
\hline & \multicolumn{7}{|c|}{ Immunological parameters } & \multicolumn{3}{|c|}{ Day of illness } \\
\hline Serum & sCD23 & $\mathrm{IgE}$ & IL-2 & sIL-2R $\alpha$ & IL-6 & IL-6sR & $\mathrm{TNF}-\alpha$ & Mean & Min. & Max. \\
\hline $1^{\text {st }}$ & 23 & 41 & 41 & 42 & 40 & 42 & 27 & 10 & 1 & 29 \\
\hline $2^{\text {nd }}$ & 12 & 16 & 17 & 17 & 18 & 18 & 12 & 19 & 7 & 41 \\
\hline & \multicolumn{7}{|c|}{ No. of sera of HFRS patients } & & & \\
\hline
\end{tabular}


used for describing the relationship between the clinical and immunological data.

The statistical software utilized was Stat Soft, Inc. STATISTICA for Windows (Computer program manual). Tulsa, OK, USA.

\section{RESULTS}

Differences in the immunological parameters during the HFRS course.

The results are presented in Figure 1. We did not find elevated IL-2 levels in the sera of our HFRS patients. In about $1 / 4$ of HFRS patients, we found elevated IL-6 levels in the 1st serum, and in the majority of them, IL- 6 reached a normal level in the second sera. No statistically significant difference was observed in
IL- 6 levels between the $1^{\text {st }}$ and the $2^{\text {nd }}$ serum. Only two patients had elevated TNF-alpha levels in their sera: one with the severe PUU infection and acute renal failure and other with severe clinical picture and DOB and leptospira coinfection. On the contrary, sIL-2R, sIL-6R and sCD23 levels were elevated in all HFRS patients, but we also did not find statistical difference between $1^{\text {st }}$ and $2^{\text {nd }}$ sera, although we observed higher sCD23 levels in the second sera. Total IgE was elevated in about $1 / 3$ of HFRS patients in both sera.

Differences in the immunological parameters between patients with PUUV or DOBV infections.

The results are showen in Figure 2. We detected higher IL-6,

Table 2. Correlation between IL-2sR-alpha, IL-6, IL-6sR, sCD23 and IgE and blood and biochemical findings in sera of patients infected with Puumala or Dobrava viruses

\begin{tabular}{|c|c|c|c|c|c|}
\hline & IL-2sR $\alpha$ & IL-6 & IL-6sR & sCD23 & IgE \\
\hline Leukocytes & $\begin{array}{c}(\mathrm{n}=37) \mathrm{r}=0,62 \\
\mathrm{p}=0,0001\end{array}$ & $\begin{array}{c}(\mathrm{n}=37) \mathrm{r}=0,36 \\
\mathrm{p}=0,03\end{array}$ & - & - & - \\
\hline Platelets & $\begin{array}{c}(\mathrm{n}=36) \mathrm{r}=-0,50 \\
\mathrm{p}=0,002\end{array}$ & - & - & - & - \\
\hline $\begin{array}{c}\text { Non-segmented } \\
\text { leukocytes }\end{array}$ & $\begin{array}{c}(\mathrm{n}=30) \mathrm{r}=0,72 \\
\mathrm{p}=0,0001\end{array}$ & - & - & $\begin{array}{c}(\mathrm{n}=24) \mathrm{r}=0,61 \\
\mathrm{p}=0,002\end{array}$ & - \\
\hline Lymphocytes & $\begin{array}{c}(\mathrm{n}=36) \mathrm{r}=-0,45 \\
\mathrm{p}=0,006\end{array}$ & $\begin{array}{c}(\mathrm{n}=36) \mathrm{r}=-0,63 \\
\mathrm{p}=0,0001\end{array}$ & - & - & - \\
\hline Basophiles & - & - & - & - & $\begin{array}{c}(\mathrm{n}=13) \mathrm{r}=0,80 \\
\mathrm{p}=0,001\end{array}$ \\
\hline Total protein & $\begin{array}{c}(\mathrm{n}=17) \mathrm{r}=-0,87 \\
\mathrm{p}=0,0001\end{array}$ & - & $\begin{array}{c}(\mathrm{n}=18) \mathrm{r}=0,53 \\
\mathrm{p}=0,02\end{array}$ & - & $\begin{array}{c}(\mathrm{n}=19) \mathrm{r}=-0,72 \\
\mathrm{p}=0,0001\end{array}$ \\
\hline Albumin & $\begin{array}{c}(\mathrm{n}=17) \mathrm{r}=-0,58 \\
\mathrm{p}=0,01\end{array}$ & - & - & - & $\begin{array}{c}(\mathrm{n}=19) \mathrm{r}=0,49 \\
\mathrm{p}=0,03\end{array}$ \\
\hline Globulins & $\begin{array}{c}(\mathrm{n}=17) \mathrm{r}=-0,69 \\
\mathrm{p}=0,002\end{array}$ & - & - & - & $\begin{array}{c}(\mathrm{n}=21) \mathrm{r}=-0,55 \\
\mathrm{p}=0,01\end{array}$ \\
\hline$\gamma$-globulin & - & $\begin{array}{c}(\mathrm{n}=20) \mathrm{r}=-0,46 \\
\mathrm{p}=0,0001\end{array}$ & - & - & - \\
\hline Urea & $\begin{array}{c}(\mathrm{n}=38) \mathrm{r}=0,71 \\
\mathrm{p}=0,0001\end{array}$ & $\begin{array}{c}(\mathrm{n}=38) \mathrm{r}=0,41 \\
\mathrm{p}=0,01\end{array}$ & $\begin{array}{c}(\mathrm{n}=39) \mathrm{r}=0,53 \\
\mathrm{p}=0,0001\end{array}$ & $\begin{array}{c}(\mathrm{n}=27) \mathrm{r}=0,61 \\
\mathrm{p}=0,001\end{array}$ & - \\
\hline Creatinine & $\begin{array}{c}(\mathrm{n}=38) \mathrm{r}=0,68 \\
\mathrm{p}=0,0001\end{array}$ & $\begin{array}{c}(\mathrm{n}=38) \mathrm{r}=0,36 \\
\mathrm{p}=0,03\end{array}$ & $\begin{array}{c}(\mathrm{n}=39) \mathrm{r}=0,52 \\
\mathrm{p}=0,001\end{array}$ & $\begin{array}{c}(\mathrm{n}=28) \mathrm{r}=0,64 \\
\mathrm{p}=0,0001\end{array}$ & - \\
\hline $\mathrm{Na}^{+}$ & $\begin{array}{c}(\mathrm{n}=37) \mathrm{r}=-0,70 \\
\mathrm{p}=0,0001\end{array}$ & $\begin{array}{c}(\mathrm{n}=37) \mathrm{r}=-0,49 \\
\mathrm{p}=0,002\end{array}$ & $\begin{array}{c}(\mathrm{n}=38) \mathrm{r}=-0,42 \\
\mathrm{p}=0,009\end{array}$ & $\begin{array}{c}(\mathrm{n}=26) \mathrm{r}=-0,60 \\
\mathrm{p}=0,001\end{array}$ & $\begin{array}{c}(\mathrm{n}=35) \mathrm{r}=-0,42 \\
\mathrm{p}=0,01\end{array}$ \\
\hline $\mathrm{Cl}^{-}$ & $\begin{array}{c}(\mathrm{n}=37) \mathrm{r}=-0,60 \\
\mathrm{p}=0,0001\end{array}$ & $\begin{array}{c}(\mathrm{n}=37) \mathrm{r}=-0,41 \\
\mathrm{p}=0,01\end{array}$ & $\begin{array}{c}(\mathrm{n}=38) \mathrm{r}=-0,32 \\
\mathrm{p}=0,05\end{array}$ & $\begin{array}{c}(\mathrm{n}=26) \mathrm{r}=-0,61 \\
\mathrm{p}=0,001\end{array}$ & - \\
\hline Total bilirubin & $\begin{array}{c}(\mathrm{n}=27) \mathrm{r}=0,64 \\
\mathrm{p}=0,0001\end{array}$ & - & - & - & $\begin{array}{c}(\mathrm{n}=26) \mathrm{r}=0,49 \\
\mathrm{p}=0,01\end{array}$ \\
\hline AST & $\begin{array}{c}(\mathrm{n}=27) \mathrm{r}=0,71 \\
\mathrm{p}=0,0001\end{array}$ & - & - & - & $\begin{array}{c}(\mathrm{n}=28) \mathrm{r}=0,49 \\
\mathrm{p}=0,008\end{array}$ \\
\hline$\gamma-G T$ & $\begin{array}{c}(\mathrm{n}=27) \mathrm{r}=0,39 \\
\mathrm{p}=0,05\end{array}$ & - & - & - & $\begin{array}{c}(\mathrm{n}=26) \mathrm{r}=0,58 \\
\mathrm{p}=0,002\end{array}$ \\
\hline
\end{tabular}

$\mathrm{Na}^{+}$, sodium, $\mathrm{Cl}^{-}$, chloride; AST, aspartate, $\gamma$-GT, $\gamma$-glutamil transferase 
IL-2
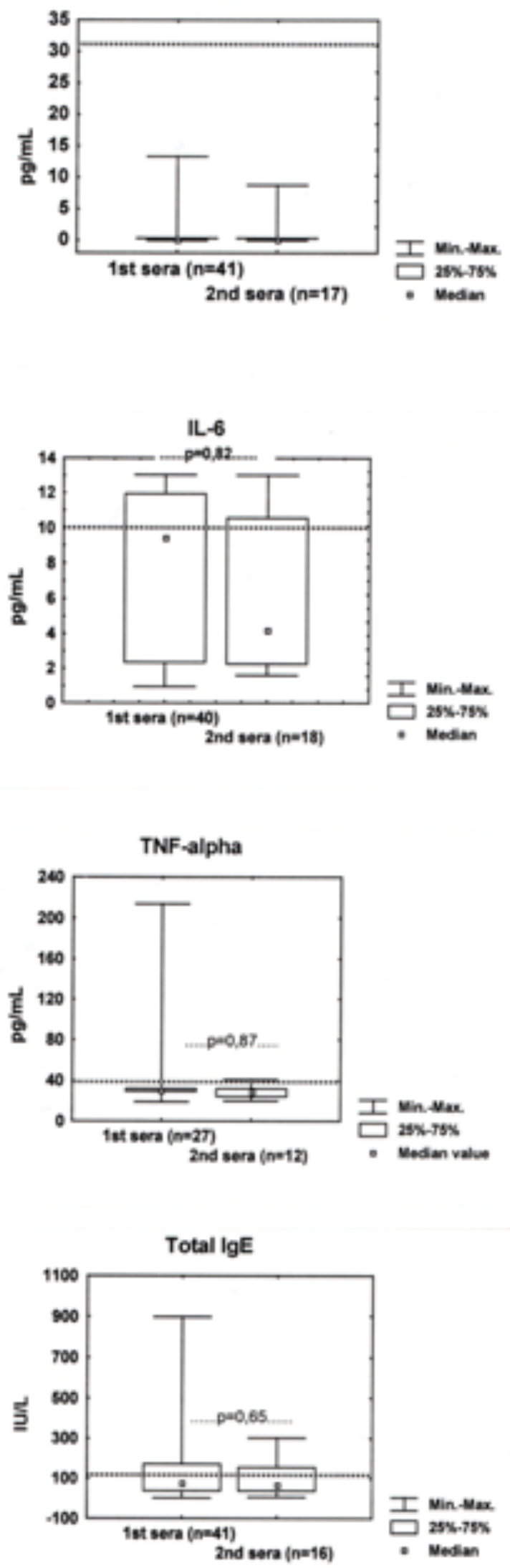
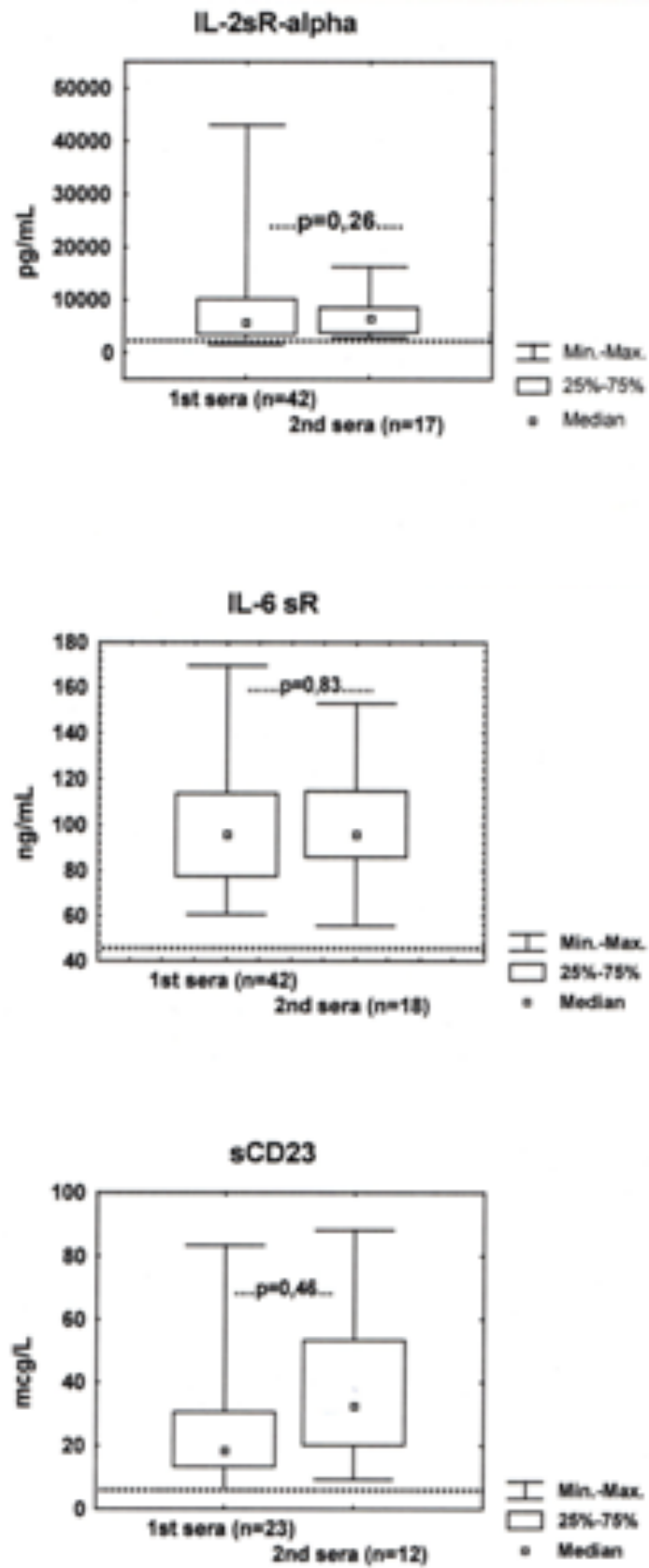

Figure 1. Differences in the immunological parameters during HFRS course. Statistical difference in the levels of measured parameters between 1st and 2nd sera was not observed (Wilcoxon test; significant at $p<0.05$ ). The broken line represents the healthy controls upper limit for tested parameters. 
$\mathrm{IL}-2$

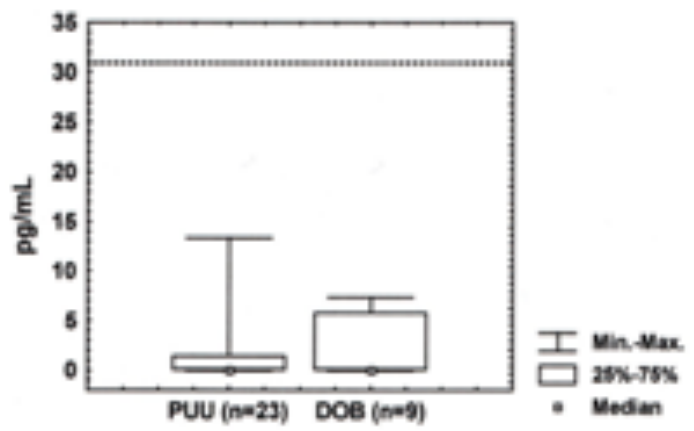

IL-6

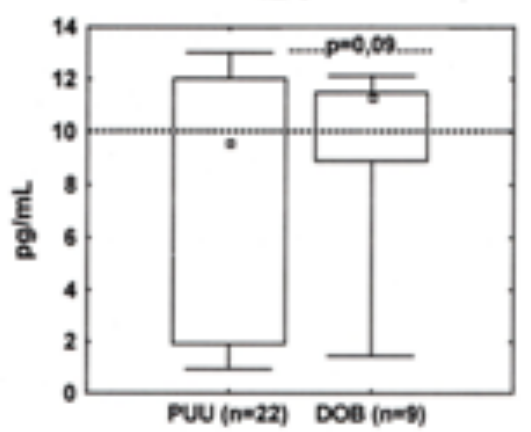

I Nin.Max. $\square$ 25\%-75\% - Medan
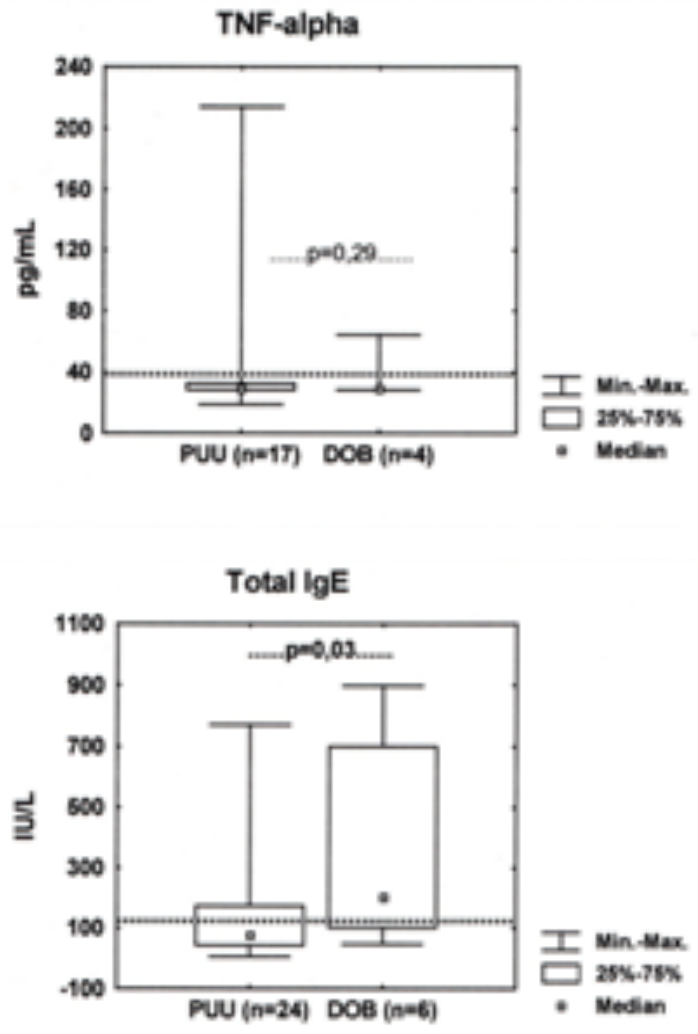
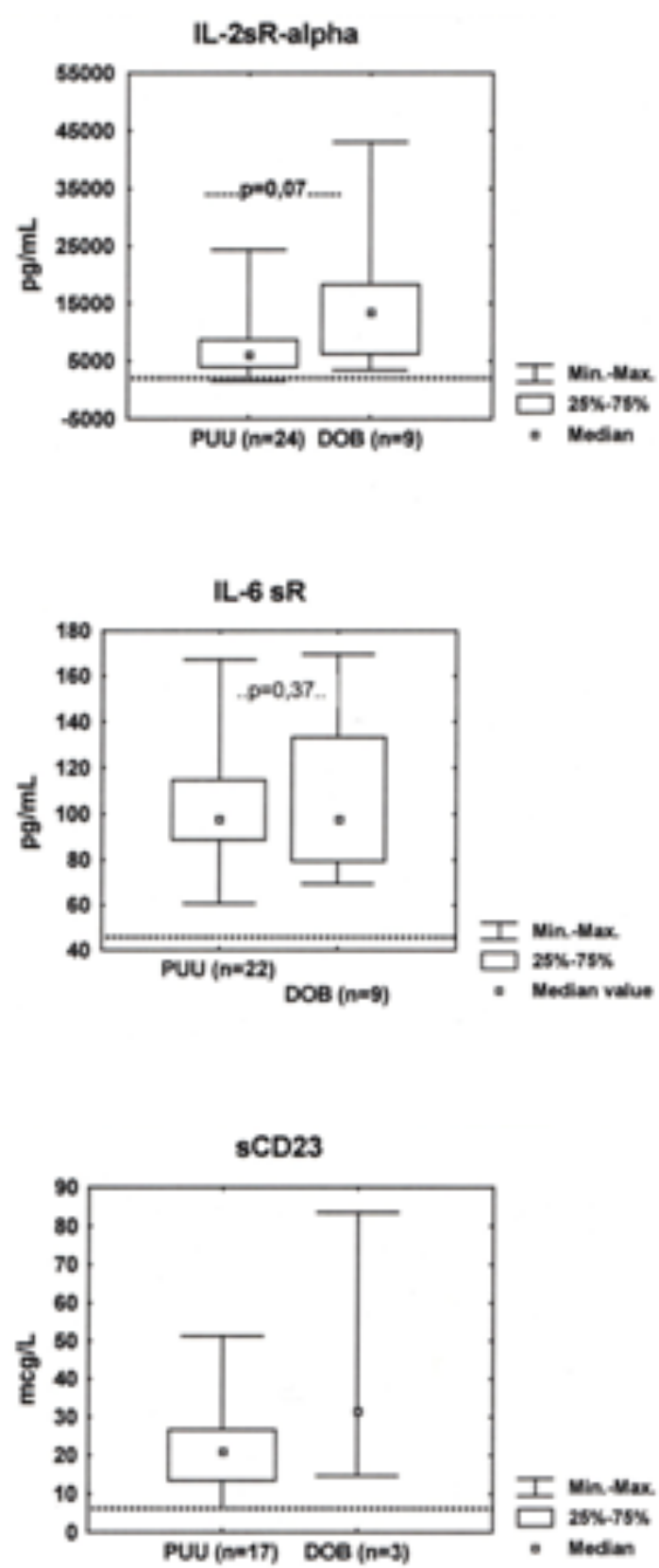

Figure 2. Differences in the immunological parameters in patients infected with Puumala or Dobrava viruses. A statistically significant higher level of total IgE was observed in patients infected with Dobrava virus (Wilcoxon test; significant at $p<0.05)$. The broken line represents the healthy controls upper limit for tested parameters. 
sIL-2R and sCD23 levels in the sera of patients with DOBV infection than in patients with PUUV infection, but a statistically significant difference was not observed. There was no difference in TNF-alpha and sIL-6R levels between PUU and DOB patients. The total IgE level was elevated in five of the six tested patients with DOBV infection and they had a statistically higher level of total IgE than patients with PUUV infection.

\section{The relation between main laboratory biochemical and blood find- ings and immunological parameters.}

The main altered biochemical and blood findings in HFRS patients and their relation to the measured immunological parameters are presented in Table 2. We could see that almost all listed biochemical and blood parameters in HFRS patients are in a positive or negative correlation with sIL-2R-alpha. The levels of urea and creatinine, which are the hallmarks of the HFRS severity are in positive correlation with sIL-2R-alpha, IL-6, sIL$6 \mathrm{R}$, and $\mathrm{s} \mathrm{CD} 23$, while the levels of sodium and chloride are in negative correlation with the same parameters, as well as with the total IgE. The level of total IgE is in positive or negative correlation with proteins and parameters of liver function. We also found a high positive correlation between the total $\mathrm{IgE}$ level and basophile count.

\section{DISCUSSION}

It is important to determine different immunological parameters which may have a role in the pathogenesis of HFRS. Such information may lead to a better understanding of the different mechanisms of immunopathogenesis in HFRS.

This study is among very few studies that analyze differences in some immunological parameters in patients with PUUV or DOBV infections ${ }^{16,21}$ and their relationship with some biochemical and blood findings. Previously, we described immunophenotypic changes in peripheral blood lymphocytes and their relationship with the clinical parameters. We found the increased expression of both early and late $\mathrm{T}$ cell activation antigens, e.g. CD25, CD71 and HLA-DR, memory cells and $s \mathrm{CD} 23$ in seropositive patients, but we did not find any significant differences in those parameters between the patients infected with PUUV or DOBV ${ }^{16}$.

Several authors found an increased level of sIL-2R, which was in concordance with HFRS severity ${ }^{17-19}$. It is known that the measurement of IL-2sR is a useful parameter for in vivo determination of immune system activation in correlation with the clinical picture. IL-2sR-alpha was increased in all Croatian HFRS patients and showed a positive or negative correlation with the majority of biochemical and blood findings. We realized that the level of IL-2sR was increased when biochemical parameters and blood findings, which indicate the progression of HFRS, were changed.

Looking for the difference of IL-2sR levels between patients with PUUV and DOBV infections we observed a higher level of IL-2sR in patients with DOBV infection. The difference was not significant $(\mathrm{p}<0.07)$, but we considered that if we had a larger population of patients with DOBV infection, we might get a statistically significant difference.

The serum level of IL-2 was not elevated in patients with PUU or DOBV infections. It is possible that IL-2sR-alpha could regulate the activation of T-lymphocytes by competition for IL-2 and decreased or stopped the proliferation of activated T-lymphocytes. Because of the higher levels of IL-2sR-alpha DOBV patients and the severe clinical picture, it would be interested to analyze T-cell activation and IL-2sR-alpha levels in that patients continuously during the HFRS course and in convalescence. However, we observed in few HFRS patients that IL-2sR-alpha levels decreased from the beginning of HFRS to the period of convalescence and that the highest levels we could find during the first week of HFRS. (A. Markotić, unpublished results).

The few studies in patients with HTNV or PUUV infections showed that proinflammatory cytokines IL-1, IL-6, and TNF-alpha have a role in HFRS pathogenesis ${ }^{9-12}$. We found elevated levels of IL- 6 in about $1 / 4$ of our patients and the higher levels we observed in patients with DOBV infection. All tested patients with PUUV or DOBV infection had elevated levels of IL-6sR while TNF-alpha was increased only in few HFRS patients with the severe clinical picture, as well as in one patient with D0BV and leptospira coinfection.

One of the postulates in HFRS pathogenesis is that it is immunologically mediated disease with thrombocytopenia and vascular dysfunction (mainly due to capillary leakage) as the central physiologic derangement. Endothelial cells, together with monocytes/macrophages are supposed as the main target cells for hantaviruses. Vascular cells are both targets for cytokines and a source of cytokines. However, in HFRS, monocytes/macrophages also could be an important source of secreting cytokines, complement components and coagulation factors ${ }^{8}$. Linderholm et al. found increased levels of TNF-alpha in serum samples of patients with acute PUUV infection ${ }^{10}$. In our study, we did not find elevated serum TNF-alpha levels in the majority of our HFRS patients, however, we found it in a few patients with severe HFRS.

The sera of majority of our patients were tested on TNF-alpha during the second week of HFRS when we can expect a decrease of TNF-alpha in HFRS patients. It is probably the reason why we did not find more HFRS patients with elevated TNF-alpha levels. Our results indicated that we could expect increased levels of TNF-alpha in severe HFRS clinical picture. In all Croatian HFRS patients, we detected elevated IL-6sR levels which were in high positive correlation with urea and creatinine. IL- 6 and alpha-chain of IL- 6 receptor make a complex which binds gp 130, a molecule of high transducing affinity for IL-6, and enhance IL-6 mediated signal to the target cell. IL-6 can also induce the liver to enhance the synthesis and secretion 
of acute phase proteins.

The role of cytokine production by different cell types involved in the pathogenesis of HVBS is not clear. We assume that investigations that would allow simultaneous detection of cytokines and cell phenotype could partially clarify this role. Such information can lead to a better understanding of the different mechanisms of immunopathogenesis in HFRS, as well as differ- ent clinical manifestations.

Author CONTRIBUtions:

All authors listed have made a substantial, direct and intellectual contribution to the work, and approved it for publication.

\section{LITERATURE:}

1. Lefkowitz EJ, Dempsey DM, Hendrickson RC, Orton RJ, Siddell SG, Smith DB. Virus taxonomy: the database of the International Committee on Taxonomy of Viruses (ICTV). Nucleic Acids Res. 2018;46(D1): D708-D717. doi:10.1093/nar/gkx932

2. Schmaljohn C, Hjelle B. Hantaviruses: a global disease problem. Emerg Infect Dis. 1997;3(2):95-104. doi:10.3201/eid0302.970202 3. Mustonen J, Brummer-Korvenkontio M, Hedman K, Pasternack A, Pietilä K, Vaheri A. Nephropathia epidemica in Finland: a retrospective study of 126 cases. Scand J Infect Dis. 1994; 26(1): 7-13. 4. Markotić A, Nichol ST, Kuzman I, Sanchez AJ, Ksiazek TG, Gagro A, Rabatić S, Zgorelec R, Avsic-Zupanc T, Beus I, Dekaris D. Characteristics of Puumala and

Dobrava infections in Croatia. J Med Virol. 2002 Apr;66(4):542-51. 5. Avšič Županc T, Korva M, Markotić A. HFRS and hantaviruses in the Balkans/South-East Europe. Virus Res. 2014 Jul 17;187:27-33.

6. Mustonen J, Partanen J, Kanerva M et al.Genetic susceptibility to severe course of nephropathia epidemica caused by Puumala hantavirus. Kidney International 1996; 49: 217-221.

7. Jiang H, Du H, Wang LM, Wang PZ, Bai XF. Hemorrhagic Fever with Renal Syndrome: Pathogenesis and Clinical Picture. Front Cell Infect Microbiol. 2016;6:1. Published 2016 Feb 3. doi:10.3389/ fcimb.2016.00001

8. Cosgriff TM, Lewis RM. Mechanisms of disease in hemorrhagic fever with renal syndrome. Kidney Int Suppl 1991;35:72-9.

9. Krakauer T, Leduc JW, Krakauer H. Serum levels of tumor necrosis factor-alpha, interleukin-1, and interleukin-6 in hemorrhagic fever with renal syndrome. Viral Immunol. 1995;8(2):75-9.

10. Linderholm M, Ahlm C, Settergren B, Waage A, Tärnvik A. Elevated plasma levels of tumor necrosis factor (TNF)-alpha, soluble TNF receptors, interleukin (IL)-6, and IL-10 in patients with hemorrhagic fever with renal syndrome. J Infect Dis. 1996 Jan;173(1):38-43.

11. Markotić A, Gagro A, Dasić G et al. Immune parameters in hemorrhagic fever with renal syndrome during the incubation and acute disease: case report. Croat Med J. 2002 Oct;43(5):587-90. 12. Guo J, Guo X, Wang Y, Tian F, Luo W, Zou Y. Cytokine response to Hantaan virus infection in patients with hemorrhagic fever with renal syndrome. J Med Virol. 2017 Jul;89(7):1139-1145. doi: 10.1002/jmv.24752. Epub 2017 Feb 10

13. Khaiboullina SF, Levis S, Morzunov SP, Martynova EV, Anokhin VA, Gusev OA, St Jeor SC, Lombardi VC, Rizvanov AA. Serum Cytokine Profiles Differentiating Hemorrhagic Fever with Renal Syndrome and Hantavirus Pulmonary Syndrome. Front Immunol. 2017 May 18;8:567. doi: 10.3389/fimmu.2017.00567.

14. Alexeyev OA, Linderholm M, Elgh F, Wadell G, Juto P, Tärnvik A. Increased plasma levels of soluble CD23 in haemorrhagic fever with renal syndrome; relation to virus-specific IgE. Clin Exp Immunol 1997;109(2):351-5.

15. Alexeyev OA, Ahlm C, Billheden J, Settergren B, Wadell G, Juto P. Elevated levels of total and Puumala virus-specific immunoglobulin E in the Scandinavian type of hemorrhagic fever with renal syndrome. Clin Diagn Lab Immunol 1994;1(3):269-72.

16. Markotić A, Dasić G, Gagro A, Sabioncello A, Rabatić S, Kuzman I, Zgorelec R, Smoljan I, Beus I, Zupanc TA, Dekaris D. Role of peripheral blood mononuclear cell (PBMC) phenotype changes in the pathogenesis of haemorrhagic fever with renal syndrome (HFRS). Clin Exp Immunol. 1999 Feb;115(2):329-34.

17. Huang C, Jin B, Wang M, Li E, Sun C. Hemorrhagic fever with renal syndrome: relationship between pathogenesis and cellular immunity. J Infect Dis. 1994;169(4):868-70.

18. Takala A, Lähdevirta J, Jansson SE, Vapalahti O, Orpana A, Karonen SL, Repo H. Systemic inflammation in hemorrhagic fever with renal syndrome correlates with hypotension and thrombocytopenia but not with renal injury. J Infect Dis. 2000 Jun;181(6):196470.

19. Liu JM, Zhu Y, Wang JP, Ouyang WM, Li Q, Zhuang R, Jin BQ. [Changes and significance of TNF, sIL-2R, IL-6, IL-4 and IFN-gamma levels in plasma from the patients with hemorrhagic fever with renal syndrome]. Xi Bao Yu Fen Zi Mian Yi Xue Za Zhi. 2004 Nov;20(6):744-6.

20. Gagro A, Rabatić S, Trešćec A, Dekaris D, Medar-Lasić M. Expression of lymphocytes Fc-alpha-RII/CD23 in allergic children undergoing hyposensitization. Int Arch Allergy Immunol. 1993; 101:203-8.

21. Korva M, Saksida A, Kejžar N, Schmaljohn C, Avšič-Županc T. Viral load and immune response dynamics in patients with haemorrhagic fever with renal syndrome. Clin Microbiol Infect. 2013 Aug;19(8):E358-66. 